\title{
Analysis of phenotypes altered by temperature stress and hipermutability in Drosophila willistoni
}

\author{
Marícia F. D’Ávila ${ }^{1}$, Rosane N. Garcia², Elgion L. S. Loreto ${ }^{1}$ \& Vera Lúcia da S. Valente ${ }^{1}$
}

1. Departamento de Genética, Instituto de Biociências, Universidade Federal do Rio Grande do Sul, Av. Bento Gonçalves 9500, Bloco B, Prédio 43323, Caixa Postal 15053, 91501-970 Porto Alegre, RS, Brazil. (maryfantinel@gmail.com)

2. Programa de Pós-Graduação em Biologia Animal, Departamento de Zoologia, Universidade Federal do Rio Grande do Sul. Caixa Postal 15053, 91501-970 Porto Alegre, RS, Brazil.

\begin{abstract}
Drosophila willistoni (Sturtevant, 1916) is a species of the willistoni group of Drosophila having wide distribution from the South of USA (Florida) and Mexico to the North of Argentina. It has been subject of many evolutionary studies within the group, due to its considerable ability to successfully occupy a wide range of environments and also because of its great genetic variability expressed by different markers. The $D$. willistoni 17A2 strain was collected in 1991 in the state of Rio Grande do Sul, Brazil (3005’S, 51³9’W), and has been maintained since then at the Drosophila laboratory of UFRGS. Different to the other D. willistoni strains maintained in the laboratory, the 17A2 strain spontaneously produced mutant males white-like (white eyes) and sepia-like (brown eyes) in stocks held at $17^{\circ} \mathrm{C}$. In order to discover if this strain is potentially hypermutable, we submitted it to temperature stress tests. Eighteen isofemale strains were used in our tests and, after the first generation, all the individuals produced in each strain were maintained at $29^{\circ} \mathrm{C}$. Different phenotype alterations were observed in subsequent generations, similar to mutations already well characterized in D. melanogaster (white, sepia, blistered and curly). In addition, an uncommon phenotype alteration with an apparent fusion of the antennae was observed, but only in the isofemale line $\mathrm{n}^{\circ}$ 31. This last alteration has not been previously described as a mutation in the $D$. melanogaster species. Our results indicate that the $D$. willistoni 17A2 strain is a candidate for hypermutability, which presents considerable cryptic genetic variability. Different factors may be operating for the formation of this effect, such as the mobilization of transposable elements, effect of inbreeding and alteration of the heat-shock proteins functions.
\end{abstract}

KEYWORDS. D. willistoni, 17A2 strain, temperature stress, genetic variability, hypermutability.

RESUMO. Análises de fenótipos alterados pelo stress de temperatura e hipermutabilidade em Drosophila willistoni. Drosophila willistoni (Sturtevant, 1916) é uma espécie do grupo willistoni de Drosophila que apresenta ampla distribuição geográfica desde o sul dos Estados Unidos (Flórida) e México até o norte da Argentina. Esta espécie tem sido alvo de muitos estudos evolutivos dentro do grupo devido à sua considerável capacidade de explorar de forma bem sucedida diversos tipos de ambientes e também por sua grande variabilidade genética expressa através de diferentes marcadores. A linhagem 17A2 de D. willistoni foi coletada em 1991 no Estado do Rio Grande do Sul, Brasil ( $\left.30^{\circ} 05^{\prime} \mathrm{S}, 5^{\circ} 39^{\prime} \mathrm{W}\right)$, e vem sendo mantida desde então no laboratório de Drosophila da Universidade Federal do Rio Grande do Sul. Diferentemente das demais linhagens de $D$. willistoni mantidas no laboratório, a linhagem 17A2 já produziu espontaneamente machos do tipo white (olhos brancos) e do tipo sepia (olhos marrons) em estoques mantidos a $17^{\circ} \mathrm{C}$. A fim de avaliar se esta linhagem é potencialmente hipermutável, nós submetemo-la a experimentos de estresse por temperatura. Dezoito isolinhagens foram utilizadas e, após a primeira geração, todos os indivíduos de cada isolinhagem foram mantidos a $29^{\circ} \mathrm{C}$. Diferentes alterações foram observadas nas gerações seguintes, similares com mutações já bem caracterizadas em D. melanogaster (white, sépia, blistered e curly). Além destas, uma alteração com aparente fusão nas antenas foi encontrada, mas somente em indivíduos da isolinhagem $n^{\circ} 31$. Esta última alteração não foi previamente descrita como uma mutação na espécie $D$. melanogaster. Nossos resultados indicam que a linhagem 17A2 de D. willistoni é uma candidata a hipermutabilidade, além de apresentar uma variabilidade genética importante. Diferentes fatores podem estar atuando para a formação deste panorama observado, tais como mobilização de elementos transponíveis, seleção por endocruzamento e alteração na função de proteínas de choque térmico (heat-shock proteins).

PALAVRAS-CHAVE. D. willistoni, linhagem 17A2, estresse por temperatura, variabilidade genética, hipermutabilidade.

The 17A2 strain of Drosophila willistoni Sturtevant, 1916 was collected in 1991 at an agronomic station in Eldorado do Sul, state of Rio Grande do Sul, Brazil (30 $\left.05^{\circ} \mathrm{S}, 5^{\circ} 39^{\prime} \mathrm{W}\right)$ and since then has been maintained in the Drosophila Laboratory of the Department of Genetics at UFRGS (Universidade Federal do Rio Grande do Sul, Brazil). This strain has been used in cytogenetic studies that detected a high level of polymorphism for paracentric chromosomic inversions and male recombination (SANTOS-CoLARES et al., 2004).

Differing to the findings in the greater part of material collected in natural environments, the 17A2 strain of $D$. willistoni already presented spontaneous male mutants white-like (white eyes) and sepia-like (brown eyes) in stocks, which had been maintained at $17^{\circ} \mathrm{C}$ in laboratory. These mutations were selected by controlled crossings and stable strains were obtained.
Mutations are very rare events in nature and in Drosophila the mutation rate has been found to be of the order of 1 in 100,000, with a variation between 1 in 20,000 and 1 in 200,000 gametes (GARDNER \& SNUSTAD, 1986). When a series of spontaneous mutations occur, we can suspect of the hypermutability phenomenon.

Although spontaneous mutations have been reported in previous studies of the $D$. willistoni species, stable sibling strains from the altered phenotypes have been difficult to establish. VALIATI et al. (1999), working with individuals captured in urban sites in the state of Rio Grande do Sul noted some alterations such as a male with a small leg instead of the normal antenna and alteration of a portion of the eye tissue (ommatidia). They also observed a female with only one wing and a sterile female, which had a halter in place to the wing in the third thoracic segment. In this case, the efforts to establish mutant isostrains were not successful. 
Only recently GoÑ et al. (2002) obtained stable strains of spontaneous mutations in $D$. willistoni from individuals collected in Montevideo, Uruguay (3453'S, $\left.56^{\circ} 16^{\prime} \mathrm{W}\right)$. Two mutations yellow-like and dull red-like were segregated from F2 of the EM1.00 strain. In later generations white and pink mutations appeared. All the mutant strains demonstrated good viability. By controlled crossings with subsequent cytogenetic analysis, it was shown that the white, pink and yellow loci are located in the $\mathrm{X}$ chromosome.

An alteration in the eye with a phenotype similar to the mutation already described for Drosophila melanogaster Meigen, 1830 known as eyeless (ey) was also found in D. willistoni (GoÑ $e t$ al., 2002). This type of mutation, in which total or partial eye loss occurs, was analyzed at the molecular level by LuDWIG et al. (2003), but it was not possible to identify the agent responsible for this alteration. These authors suggested that the effect could be related to spot mutations, mutations in genes neighboring the ey region, or even mutations that might have occurred in another gene having a phenotype similar to the eyeless (review in GeHRING, 2001).

Some environmental factors, such as chemical or physical stress may favor the appearance of morphological alterations due to intrinsic genetic or physiological events, such as: 1) mobilization of the Transposable Elements (TEs) in the host genome, (revision by CAPY et al., 1998); 2) selection by inbreeding, where a population is generated from only a few individuals (LOESCHCKE et al., 1997); 3) and by alterations involving Heat -Shock Proteins (HSPs) during development (Petersen \& Young, 1991). This latter possibility does not necessarily involve changes in the DNA sequences, but alterations in the expressivity of the cryptic genetic variability (RUTHERFORD \& LINDQÜIST, 1998).

As all the organisms are strongly affected by their surrounding environments, the environmental factors play an important part in shaping the ecology and evolution of biological systems. Environmental stresses are especially important at many levels of biological organization (HofFMAnN \& PARsons, 1997; HofFMAnN \& Hercus, 2000), and one of the ways by which virtually all organisms combat stress is through the heat-shock response (LINDQUIST \& CRAIG, 1988; MoRIMOTO et al., 1994; FEDER \& HOFFMANN, 1999).

Heat-shock proteins (HSPs) are the main constituents of this response and typically function as molecular chaperones, which assist in maintaining cellular protein structure. In Drosophila, during thermal stress, occurs the synthesis of these proteins (SørEnsen et al., 2003) and the members of the Hsp70, for example family, are capable of mitigate cellular damage (LINDQUIST, 1981; PARSELL et al., 1993; KREBS \& LOESCHCKE, 1994; FEDER et al., 1996; SøRENSEN et al., 2003; Gong \& Golic, 2006). However, a cost of expressing the heat-shock response was identified and the increased survival after acclimation is accompanied by reduced fertility (LOESCHCKE et al., 1997).

The Hsp90 was proposed to act as a general evolutionary capacitor by releasing the effect of cryptic genetic variation under stressful environment (RUTHERFORD \& LINDQUIST, 1998). However, more recent studies have revealed that the influence of Hsp90 on the variation of particular traits was very limited (MiLTon et al., 2005). This suggests that the ability of chaperones, and Hsp90 in particular, to buffer phenotypic variation is not so general, but might rely on very specific interactions more tightly involved in particular phenotypes. Recent studies in $D$. melanogaster make a link between chaperones and chromatin regulators. Cold temperature induces a dark pigmentation, in particular in posterior segments, while higher temperature has the opposite effect. The homeotic gene Abdominal-B (Abd-B) has a major role in the plasticity of pigmentation in the abdomen. Temperature acts on melanin production by modulating a chromatin regulator network, interacting genetically with the transcription factor bric-a-brac (bab), a target of AbdB and Hsp83, encoding the chaperone Hsp90. Genetic disruption of this chromatin regulator network increases the effect of temperature and the instability of the pigmentation pattern in the posterior abdomen (review in GILBERT et al., 2007). Interesting, evidences show that Drosophila heat-shock genes are especially susceptible to the insertion of Transposable Elements (TEs) in nature and this can have dramatic fitness consequences, creating variation on which selection can act (WALSER et al., 2006; CHEN et al., 2007).

Transposable Elements (TEs) constitute a substantial component of the Drosophila genome (LinDSLEY \& ZiMM, 1992). According to experimental estimates (HARAdA et al., 1990; NuzHDin \& MACKAY, 1995), the rates of spontaneous transpositions are approximately $10^{-5}-10^{-6}$ events per TE copy per sperm per generation. Direct and indirect evidence has accumulated in favors of the phenomenon of TE transposition being induced by external stress factors, of which temperature treatment and $\gamma$-irradiation are the most important. It was demonstrated that heat shock induces transcription (necessary for retrotransposition) of the copia retrotransposon (STRAnd \& McDonald, 1985). However, the control of TE activity is dependent of the host genome and its interaction with environmental factors. In Drosophila, some retrotransposons were mobilized after heat-shocks in certain laboratory lines (RATNER et al., 1992; ZaBANOv et al. 1994; VASILYEVA et al., 1999), while in other experiments that effect was not found (ARnault et al., 1997; VÁzquez et al., 2007).

In view of the appearance of spontaneous mutations in the 17A2 strain and the possibility that this might be a clue to the identification of agents responsible for the variability of this species, we designed this study to identify different alterations in the phenotypes which occur when individuals of this strain are submitted to physical stress (by temperature increase), as well as to describe in detail the type of alteration found in the antenna morphology, herein demonstrated for the first time for the Drosophila genus.

Because the species $D$. willistoni presents extensive genetic variability expressed by various markers such as polymorphism chromosomal for paracentric inversions and enzymatic polymorphism (AyAla \& Powell, 1972), a descriptive investigation such as we present in this study can provide a base for future research, which could lead to a better understanding of the possible causative agents of this $D$. willistoni genetic variability. 


\section{MATERIAL AND METHODS}

The stocks of $D$. willistoni populations were maintained by general massal crosses in a standard culture medium (MARQUEs et al., 1966) inside a chamber kept at a constant temperature of $17^{\circ} \mathrm{C} \pm 1^{\circ} \mathrm{C}$ with approximately $60 \%$ relative humidity. Two strains were used in this work: WIP-4 (a strain maintained in laboratory since 1966 and that never presented spontaneous mutation) as negative control and 17A2 (a strain colleted in 1991), target of this work. Initially, for obtaining the isostrains of the each strain, forty natural-born virgin females and males were crossed. Only eighteen strains of each population initially selected (the number is indicating in table I), produced offspring for the continuities of the experiment. After the first generation, descendents of each of these strains were submitted to temperature stress being maintained in culture chambers at $29^{\circ} \mathrm{C}$. In each new generation, after brief anesthesia in ethylic ether and visualization on stereomicroscope, the individuals were analyzed and counted. All the mutants were removed and submitted to controlled crossings (a mutant phenotype male crossed with a wild type virgin female) in an effort to obtain stable mutant strains. The strains from the population WIP-4 did not show individuals with mutant phenotypes (data not shown). Thus, the number of controlled crossings is the number of mutant individuals obtained in each generation, for each isofemale line in 17A2 strain, as described in table I.

Individuals of wild phenotype were placed in a new culture medium to breed and deposit their eggs again. The strains were followed-up for eleven generations. The phenotypic alterations detected in each generation were photographed with a stereomicroscope. Ten male individuals of the 17A2 strain and ten of the mutant blistered strain had been dissected in EpHrussi \& BEADLE (1936) serum for the withdrawal of the testes in order to evaluate the structure, appearance and presence/absence of spermatozoa. The results of these comparative analyses were also photographed with a stereomicroscope.

Antennae that showed alterations were analyzed separately on permanent slides mounted with Entellan ${ }^{\circledR}$ (Merck). Slides visualization and image capture was achieved by using a stereomicroscope. Samples of these individuals demonstrating antennae alterations were also dehydrated and fixed for subsequent analyses of the antennae in a Scanning Electron Microscopy (SEM). Normal antennae were processed as controls. The procedures for the preparation for these samples and the image capture were made at the Electronic Microscope

Table I. Total frequency of individuals obtained in each generation in the 17A2 D. willistoni isostrains submitted to temperature stress. ( $T$, total number of individuals; $\mathrm{M}$, number of individuals with morphological alterations).

\begin{tabular}{|c|c|c|c|c|c|c|c|c|c|c|}
\hline \multicolumn{11}{|c|}{ Generation } \\
\hline Isostrain & $\mathrm{F} 2$ & F3 & $\mathrm{F} 4$ & F5 & F6 & F7 & F8 & F9 & F10 & F11 \\
\hline \multirow[t]{2}{*}{1} & $\mathrm{~T}: 216$ & $\mathrm{~T}: 145$ & $\mathrm{~T}: 158$ & $\mathrm{~T}: 84$ & $\mathrm{~T}: 123$ & $\mathrm{~T}: 88$ & T:157 & $\mathrm{T}: 110$ & $\mathrm{~T}: 77$ & $\mathrm{~T}: 41$ \\
\hline & M:1 & M:2 & M:1 & M:0 & M:2 & M:1 & M:0 & M:13 & M:0 & M:1 \\
\hline \multirow[t]{2}{*}{2} & $\mathrm{~T}: 112$ & $\mathrm{~T}: 238$ & $\mathrm{~T}: 32$ & & & & & & & \\
\hline & M:0 & M:1 & M:0 & & & & & & & \\
\hline \multirow[t]{2}{*}{4} & $\mathrm{~T}: 56$ & $\mathrm{~T}: 566$ & $\mathrm{~T}: 40$ & T:693 & & & & & & \\
\hline & M:0 & M:2 & M:0 & M:28 & & & & & & \\
\hline \multirow[t]{2}{*}{6} & $\mathrm{~T}: 47$ & $\mathrm{~T}: 472$ & $\mathrm{~T}: 199$ & $\mathrm{~T}: 122$ & $\mathrm{~T}: 114$ & & & & & \\
\hline & M:0 & M:2 & M:0 & M:1 & M:2 & & & & & \\
\hline \multirow[t]{2}{*}{7} & $\mathrm{~T}: 84$ & T:664 & $\mathrm{T}: 75$ & T:166 & & & & & & \\
\hline & M:0 & M:21 & M:1 & M:3 & & & & & & \\
\hline \multirow[t]{2}{*}{8} & $\mathrm{~T}: 124$ & $\mathrm{~T}: 31$ & & & & & & & & \\
\hline & M:0 & M:0 & & & & & & & & \\
\hline \multirow[t]{2}{*}{9} & $\mathrm{~T}: 72$ & $\mathrm{~T}: 1026$ & $\mathrm{~T}: 462$ & $\mathrm{~T}: 113$ & $\mathrm{~T}: 40$ & & & & & \\
\hline & M:0 & M:2 & M:1 & M:2 & M:5 & & & & & \\
\hline \multirow[t]{2}{*}{10} & $\mathrm{~T}: 67$ & $\mathrm{~T}: 605$ & $\mathrm{~T}: 146$ & $\mathrm{~T}: 133$ & $\mathrm{~T}: 88$ & & & & & \\
\hline & M:0 & M:3 & M:10 & M:4 & M:0 & & & & & \\
\hline \multirow[t]{2}{*}{13} & $\mathrm{~T}: 42$ & $\mathrm{~T}: 1145$ & $\mathrm{~T}: 250$ & $\mathrm{~T}: 154$ & $\mathrm{~T}: 50$ & & & & & \\
\hline & M:0 & M:12 & M:9 & M:2 & M:8 & & & & & \\
\hline \multirow[t]{2}{*}{20} & $\mathrm{~T}: 86$ & & & & & & & & & \\
\hline & M:0 & & & & & & & & & \\
\hline \multirow[t]{2}{*}{23} & $\mathrm{~T}: 155$ & $\mathrm{~T}: 23$ & $\mathrm{~T}: 11$ & & & & & & & \\
\hline & M:3 & M:0 & M:0 & & & & & & & \\
\hline \multirow[t]{2}{*}{26} & $\mathrm{~T}: 8$ & & & & & & & & & \\
\hline & M:0 & & & & & & & & & \\
\hline \multirow[t]{2}{*}{27} & $\mathrm{~T}: 256$ & $\mathrm{~T}: 113$ & $\mathrm{~T}: 62$ & & & & & & & \\
\hline & $\mathrm{M}: 2$ & M:4 & M:0 & & & & & & & \\
\hline \multirow[t]{2}{*}{28} & $\mathrm{~T}: 26$ & & & & & & & & & \\
\hline & M:0 & & & & & & & & & \\
\hline \multirow[t]{2}{*}{29} & $\mathrm{~T}: 320$ & $\mathrm{~T}: 137$ & $\mathrm{~T}: 73$ & & & & & & & \\
\hline & M:13 & M:0 & M:2 & & & & & & & \\
\hline \multirow[t]{2}{*}{30} & $\mathrm{~T}: 16$ & & & & & & & & & \\
\hline & M:0 & & & & & & & & & \\
\hline \multirow[t]{2}{*}{31} & $\mathrm{~T}: 311$ & $\mathrm{~T}: 92$ & $\mathrm{~T}: 540$ & $\mathrm{~T}: 68$ & $\mathrm{~T}: 363$ & $\mathrm{~T}: 174$ & $\mathrm{~T}: 263$ & & & \\
\hline & M:4 & M:13 & M:2 & $\mathrm{M}: 10$ & M:6 & M:4 & M:37 & & & \\
\hline \multirow[t]{2}{*}{33} & $\mathrm{~T}: 42$ & & & & & & & & & \\
\hline & M:0 & & & & & & & & & \\
\hline
\end{tabular}


Center (CME) of UFRGS (Porto Alegre, Brazil) in accordance with the standard procedures adapted at that Center. Some individuals of the isostrains presenting reduction in the number of births were dissected to find out if the reproductive structures showed any kind of alteration.

\section{RESULTS}

Of the 18 isostrains initially placed in the chamber at $29^{\circ} \mathrm{C}$, five were lost in $\mathrm{F} 2$, one in $\mathrm{F} 3$, four in $\mathrm{F} 4$, two in $\mathrm{F}$, four in F6 and one in F8 - only the 1B isostrain survived to the end of the experiment (Tab. I). In general this loss was mainly due to the gradual reduction in the number of births. The individuals of the isostrains that presented reduction in the number of births had the female gonads and the male testes morphology normal, but no spermatozoa were produced within this last (Fig. 1).
A great number of individuals with different phenotypic alterations appeared in the different isostrains analyzed (indicated by M in table I). The alterations found resembled some $D$. melanogaster mutants: white (white eyes), sepia (sepia eyes), blistered (bubbles with hemolymph in the wings) and Curly (curved wings). During the experiment two individuals with a doublemutation phenotype were observed: one white/Curlylike and the other white/blistered-like. Another alteration with the antennae apparently fused was observed. This latter alteration was found in various individuals but only in those of the isostrain number 31 (Fig. 2).

Although the morphologically altered individuals were removed from the isostrains after the count for the establishment of stable strains, the altered phenotypes continued to show up in subsequent generations (Fig. 3) suggesting that there is some factor intrinsic to the
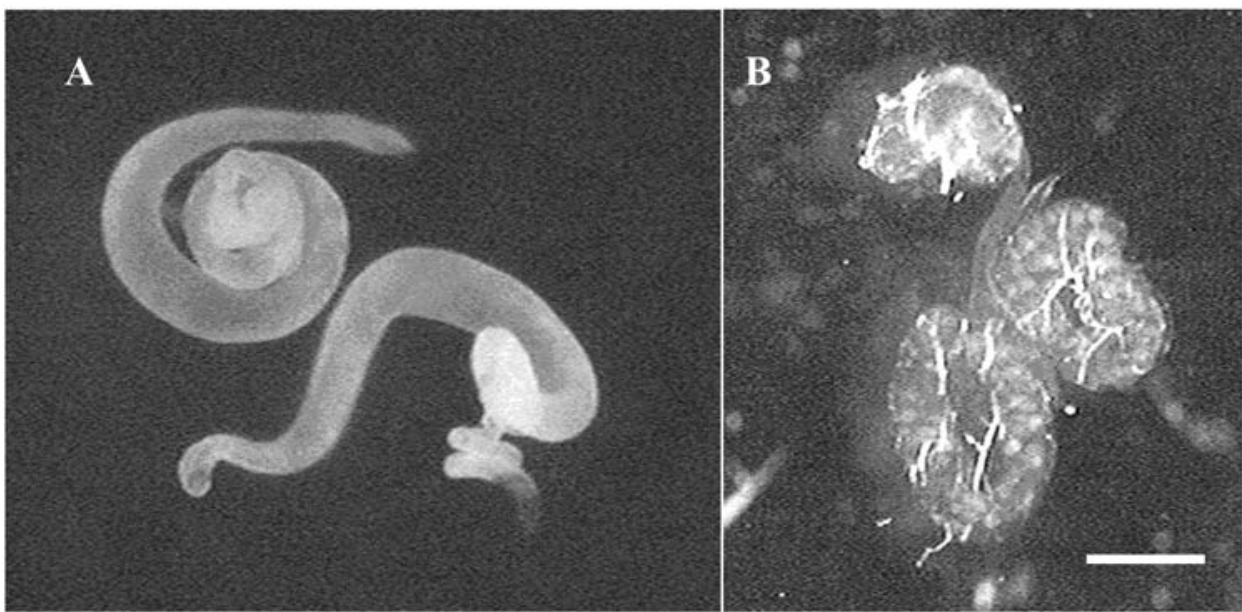

Fig. 1. Stereo microscope illustrations of the Drosophila willistoni testes. A. normal testes of a wild male of the 17A2 strain. B. Testes of a male of the blistered phenotype obtained from the isostrain 1B. The structure has a transparent aspect because no spermatozoids are present. Bar, 0.5mm
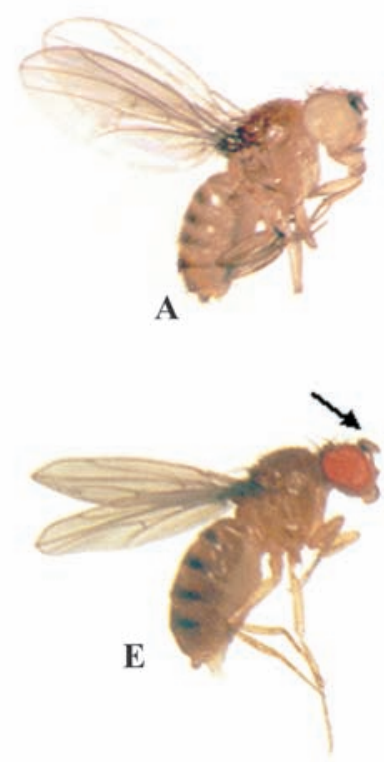

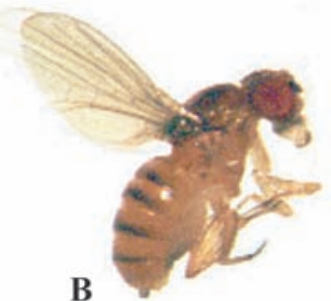

B

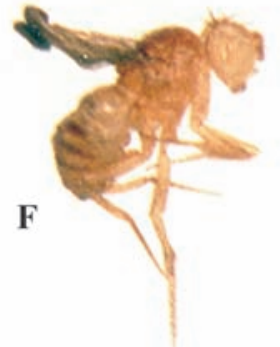

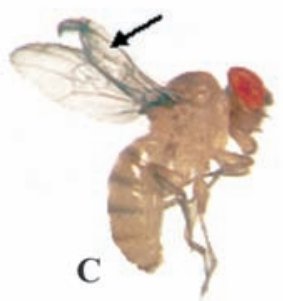
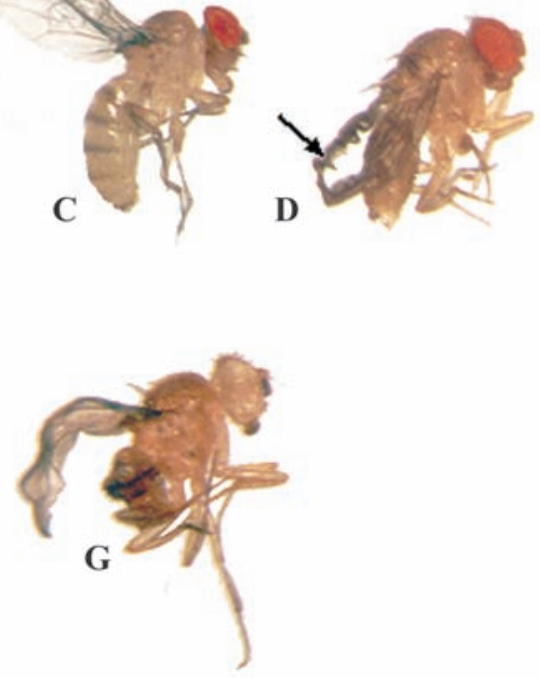

Fig. 2. Altered phenotypes obtained in individuals of Drosophila willistoni 17A2 isostrain submitted to temperature stress. Picture shows female individuals with altered morphologies: A. white (white eyes); B. sepia (brown eyes); C. blistered (arrow indicates the presence of blisters on the wings); D. Curly (curved wings indicated by the arrow); E. with apparently fused antennae (indicated by the arrow) - see figure 5 for details of the mutant structure; F. Female white and Curly; G. white and blistered. 
genomes of the individuals, that causes the reappearance of the alteration.

Of the controlled crossings carried out with the different altered phenotypes, only one strain with origin in a male blistered-like was established. This individual had been crossed with a natural-born female. The descendents of this crossing were selected and maintained in stock in the laboratory at $25^{\circ} \mathrm{C}$ for approximately eight months. However, after this period,

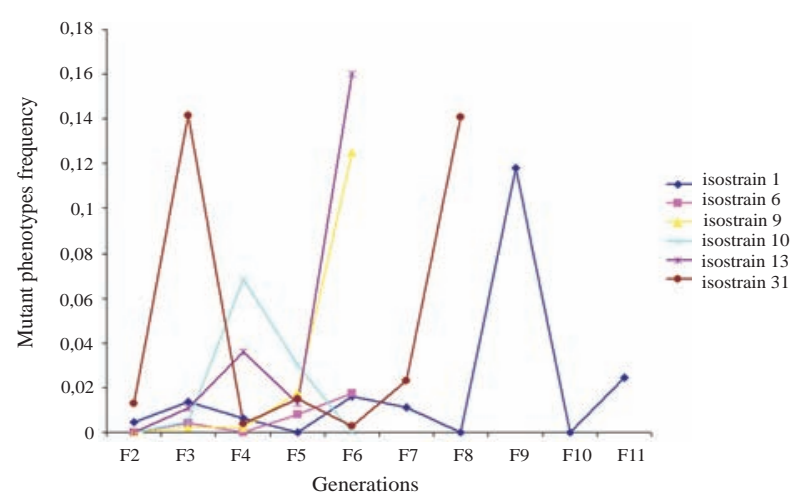

Fig. 3. Frequencies of mutant phenotypes which appeared during 11 generations in the different 17A2 isostrains (represented by different colors). The interruption in the frequency plot indicates that the isostrain was lost. Only those isostrains which remained longer in the experiment were used. the number of individuals produced gradually declined until finally the strain was entirely lost.

No previous descriptions of $D$. melanogaster individuals with the antenna alteration phenotype described here were found in the available literature. The pair of antennae is located in the frontal portion of the fly's head and is divided into four segments. In these, bristles and aristae are found and the entire structure performs hearing (GÖPFERT \& ROBERT, 2001; TODI et al., 2004) and olfactory (Fishilevich \& Vosshall, 2005) functions. A sketch of the D. melanogaster antenna structure is provided in figure 4 .

On mutants of $D$. willistoni isostrain 31 it can be seen that the altered antennae are very close to each other giving the impression when observed at glance that they form a single structure (Fig. 5). We checked that these altered antennae were not different from those observed in wild type flies as regards to the number of segments and bristles of the aristae, but these were always smaller (Fig. 6). Analyses carried out using SEM confirmed the difference in the structures size and further revealed that the antennae became approximated, giving the impression that they constituted only one structure, because they were closely implanted in the head of the flies (Fig. 7).

When crossings were made (at $25^{\circ} \mathrm{C}$ ) between the individuals carrying the antenna alterations and wild type

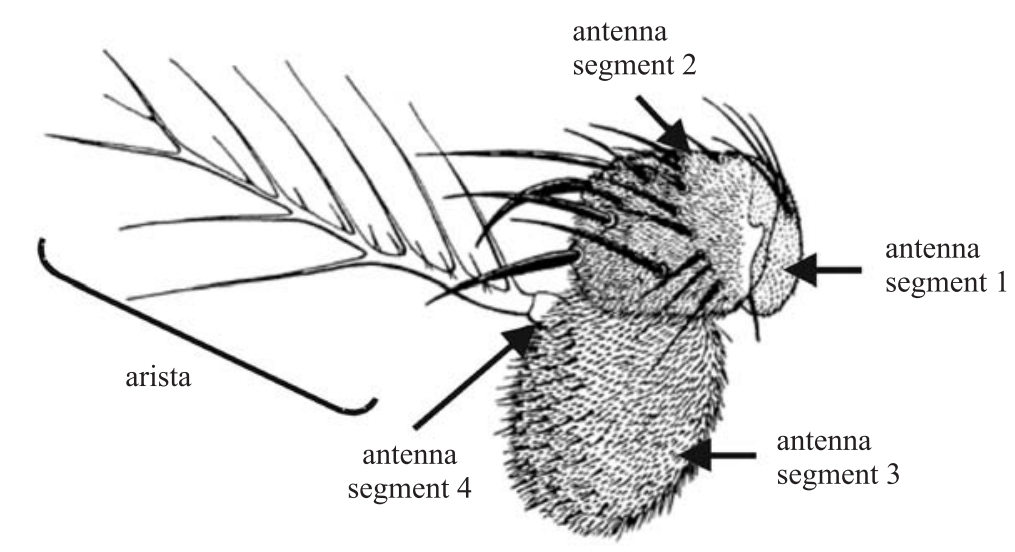

Fig 4. Sketch representing one of Drosophila melanogaster antenna with the respective structures adapted from BRYANT (1978).
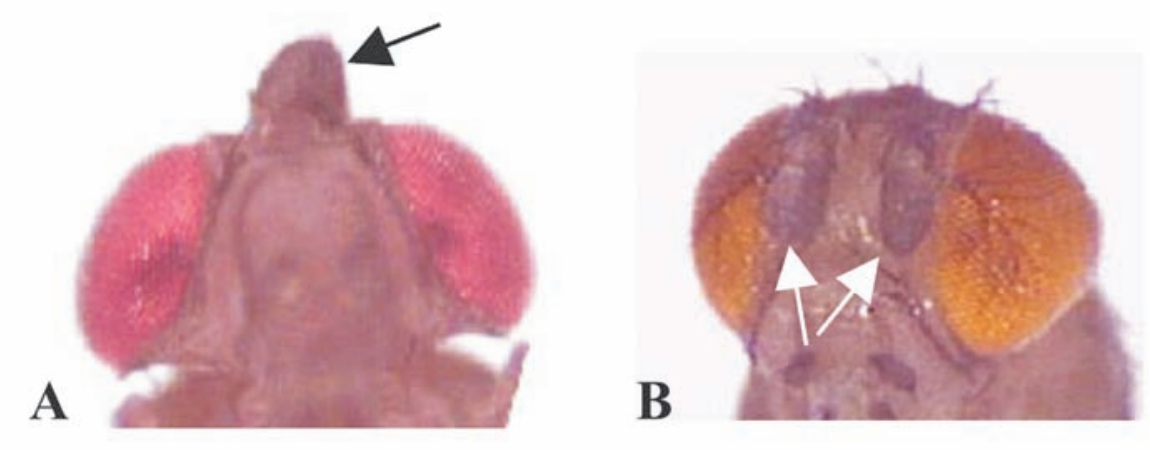

Fig. 5. Stereo microscope view of Drosophila willistoni antennae. A. An individual with altered antennae (arrow) which appeared in the isostrain 31. B. View of the antennae of a wild individual (arrows). Note that the altered antennae appear to be a single structure. Bar, $0.5 \mathrm{~mm}$ 


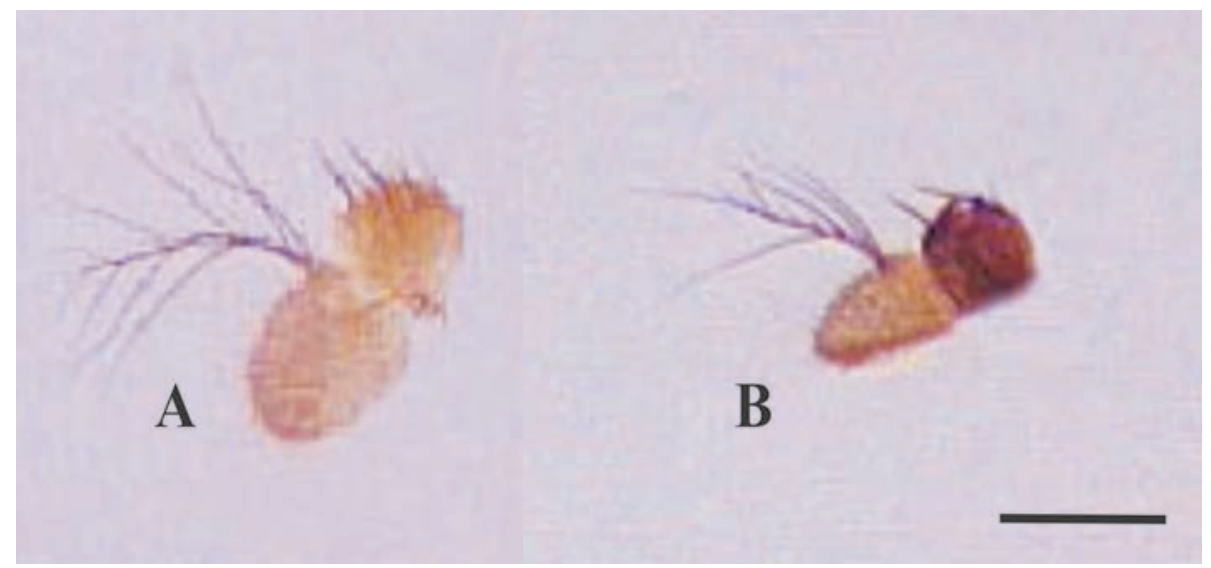

Fig. 6. Optical microscope view of de antennae of Drosophila willistoni. A. Antenna with the wild phenotype of an individual from the $17 \mathrm{~A} 2$ strain. B. Antenna with altered phenotype of an individual for isostrain 31. Bar, $0.5 \mathrm{~mm}$.

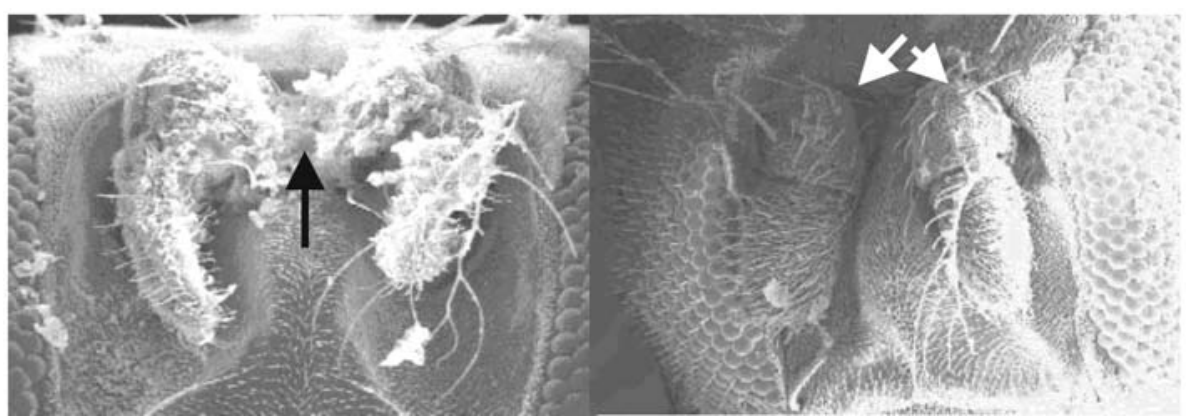

Fig. 7. Frontal view analysis of Drosophila willistoni antennae (SEM). To the left are the badly-formed antennae which occur in the individuals of the isostrain 31. Note the close implantation of the structures in the head (arrow) which is quite different from that of individuals with the wild 17A2 isostrain phenotype (to the right), where the antennae are implanted farther apart and the structures are well defined (arrows). 400X magnification.

flies, the offspring did not show the alterations presented by their parents. Despite of this, generations of the $31^{\circ}$ strain maintained at $29^{\circ} \mathrm{C}$ continued to produce these malformations. In view of this, it was not possible to derive stable strains from these individuals.

\section{DISCUSSION}

Our descriptions of the $D$. willistoni altered phenotypes produced through temperature stress indicate that an intrinsic factor in the genome of the individuals causes the alterations to appear. This idea is bourn out by the fact that the altered phenotypes continued to show up in subsequent generations, although in each generation the affected individuals were removed from isostrains after the count.

So it was not possible to relate the inviability of strain with the increased number of mutants as observed in the strains 4, 9, 13 and 31 (Tab. I). Besides this, some strains, although presented low number of mutants, were also lost after few generations. However, we cannot completely discard the possibility that the former strains could be lost due to a higher intrinsic genomic instability.

Organisms have developed a series of mechanisms to cope with environmental stress, including increased expression of stress proteins and changes in metabolism and hormone concentrations (Pletcher et al., 2002; Sørensen et al., 2005; LANDIs et al., 2004). It has been shown that some of the same mechanisms are also affected by intrinsic stresses, such as inbreeding and aging (Kristensen et al., 2005; Pletcher et al., 2002; LANDIS et al., 2004; PEDERSEn et al., 2005). The deleterious consequences of inbreeding, environmental stress and the interactions between them are of serious concern in diverse fields of biological sciences, such as evolutionary genetics, conservation biology, and animal breeding. Recently, KRISTENSEN et al. (2006) found that the effect of temperature stress on gene expression is accentuated in inbred compared to out bred lines of $D$. melanogaster. On the basis of these results the authors conclude that inbreeding and environmental stress, both independently and synergistically affect gene expression pattern. It also appears to have occurred in the present study. The majority of the alterations observed in the $D$. willistoni $17 \mathrm{~A} 2$ strain are mutations well characterized in $D$. melanogaster. Those which affect the eye pigmentation, for example, show alterations in gene sequences involved in ommatidia pigmentation metabolic pathways, and may cause the brown (sepia mutant) and white eyes (white mutant) to appear, contrary to what happens with wild type individuals who have red eyes. The white gene is involved in the production and distribution of the omochrome pigments (browns) and pteridines (reds) found in the adult flies compounding the eyes and ocelli, as well as in the adult males testes and in the larvae Malpighi tubules. The specific function of the transport 
protein, associated to the membrane, is to connect ATPprecursor pigments in the omochrome and pteridines pathways (Sullivan \& Sullivan, 1975; Dressen et al., 1988; TEARLE et al., 1989).

The sepia (se) mutant has eyes of a brown color in the eclosion, which darkens to sepia, and becomes still darker with advancing age. It has normal ocellar pigmentation. Chromographically, the se eyes are characterized by the absence of red pigments (drosopterin and isodrosopterin, for example), and by an accumulation of yellow pigments. About ten sepia alleles have been fully described for D. melanogaster (LINDSLEY \& ZIMM, 1992).

Other mutations alter the structure of the upper and lower epithelia of the wings causing curvatures (in the curly mutant) or the formation of haemolymph blisters between the epithelia (in the blistered mutant) (LINDSLEY \& ZIMM, 1992).

The Curly (Cy) is a dominant mutation in $D$. melanogaster that affects the genes necessary to form the wing structure in the adult fly. The mutation Curly, one of the most important tools in genetics analysis in Drosophila, results in curled wings at $25^{\circ} \mathrm{C}$ but in normally straight wings at $19^{\circ} \mathrm{C}$ (GRIFFITHs et al., 1996). It is used, for example, as a preferential marker of the second chromosome in genetic laboratories. The curvature of the wings in the Curly fly is caused by an unequal concentration of the upper and lower epithelia during the dry period after the emergence from the pupa (LiNDSLEY \& ZIMM, 1992).

The D. melanogaster blistered mutant, on the other hand, presents formations of haemolymph blisters between the wing surfaces. Some of these mutations are caused by defects in the Drosophila integrin proteins transmembrane heterodimers, which are part of basal junctions, and maintain the two wing surfaces united (Fristrom et al., 1993). Mutation in the integrin genes, such as inflated (if) and myosferoid (mys), cause defects in the dorsal-ventral adhesion of the wing intervenal cells also resulting in blisters on the wings (BROWER \& JAFFE, 1989; Wilcox et al., 1989; Zusman et al., 1990).

We cannot definitely state that the phenotypes observed in $D$. willistoni have their origin in the same types of mutations previously described for $D$. melanogaster, because it would be necessary to make a study at the molecular level of each type of alteration to confirm the similarity unequivocally. Moreover, the alteration resulting in jointed antennae and small aristae, which we found in the isostrain 31 of 17A2 strain, has no similar description in $D$. melanogaster. This result leads to the premise that multiple other factors may be involved in the production of the $D$. willistoni altered phenotypes which result from exposure to temperature stress. Some hypotheses for the possible agents responsible for this phenomenon are developed below.

The first hypothesis is related to mobilization of the Transposable Elements. High temperatures associate with permissive genomes (VÁzQUEz et al., 2007) may favors mobilization of these elements by an increase in the production of transposase (ENGELs, 1989) and, consequently, the phenomenon of gonadal disgenesys (Petersen \& Young, 1991). In fact, some mutations in $D$. melanogaster were characterized as being the result of the increased mobility of the Transposable Elements. The loco white of $D$. melanogaster is a hotspot for insertions presenting, for example, several alleles originated through insertions of Transposable Elements such as Doc, roo and copia (LindSLEy \& Zimm, 1992).

LORETO et al. (1998) described a hypermutable strain of $D$. simulans Sturtevant, 1919 whose causal agent was subsequently characterized as being related to the mobilization of a transposable element similar to hobo (Torres et al., 2006). Considering that the majority of Drosophila mutations are attributed to transposable element mobilizations (FINNEGAN, 1990), this would seem to be an explication pertinent to the phenomenon observed in the $D$. willistoni 17A2 strain.

Furthermore, some transposable elements are in fact present in the genome of the $D$. willistoni 17A2 strain. REGNER et al. (1996) analyzed two populations of $D$. willistoni (17A2 and WIP-4) for the presence of the $P$ transposable element, by Southern Blot and in situ hybridization, and detected the presence of apparently active $P$ element in the 17A2 strain. LoRETo et al. (1998) and SAssi et al. (2005), using the Southern blot technique, also detected the presence of sequences similar to hobo in the genome of the 17A2 strain, although with low homology to those of $D$. melanogaster.

REGNER et al. (1999) obtained phenotypic alterations in individuals of the WIP-4 and 17A2 strains in experiments, which associated controlled crossings (between and within strains) and temperature stress. The phenotypes obtained were wing alterations of the Beadexlike, held-up-like and Notch-like, as well as an eye alteration similar to extra-eye, all having been previously described for $D$. melanogaster. Some individuals with gonadal disgenesys were also obtained, very similar to what happens with $D$. melanogaster when there is mobilization of the $P$ element in its genome. This led the authors to postulate that $P$ element mobilization might be the agent causing the mutations.

Our results are similar to those obtained by REGNER et al. (1999), to the extent that we also obtained alterations in 17A2 intra-strain crossings under temperature stress. However, in our experiment the alterations are different to those previously described, which suggests that the time period during which the strain was maintained in the laboratory and new putative transpositions may have influenced the obtained results.

The existence of a relationship between environmental conditions and mobilization of TEs, however, still is an open question. In $D$. simulans natural populations, the 412 element follows a gradient in copy number between the South and North hemispheres (VIEIRA \& BiÉmont, 1996), its copy number being negatively correlated with minimum temperature (VIEIRA et al., 1998). Another example of variation in TE number related with natural environmental variation was given for BARE-1 in barley (KALENDAR et al., 2000). Less severe thermal stresses might have some effect on TE activity, for example high temperature enhances transposition of the $P$ element in dysgenic crosses (Engels \& Preston, 1980). Conversely, no effect of culture at the stress temperature of $28^{\circ} \mathrm{C}$ could be shown regarding the transposition and 
the structural mutation rate of 11 TE families (ALONsoGonZALEZ et al., 2006).

A second hypothesis that could be advanced to explain our results, especially those related to the gradual loss of the isostrains, could be the effect of depression by inbreeding, given that all isostrains were generated from one single couple. The phenomenon of depression by inbreeding is well known, being characterized by a rapid fecundity and viability decline owing to the increase of homozygotes for unfavorable alleles as the population becomes more and more inbred in the laboratory (Futuyma, 1992). The evidence that some of the males in the isostrains produced no spermatozoa supports this hypothesis.

Inbreeding can lead to a homozygozity of development genes mutant alleles which, being sensitive to temperature effects, result in phenotypes altered by stress conditions. This can have been the reason because the strains were lost after the increase of mutant individuals. Inbred populations may hardly suffer the effect of changes in the environment that non-inbred populations perceive as non-stressful, indicating that intrinsic and extrinsic stresses may interact. There is evidence that such interaction can lead to synergism between genetic and environmental stresses causing normally benign environmental conditions to become harmful (review in KRISTENSEN et al., 2006). In D. melanogaster, alleles sensitive to temperature of the ecdysoneless (ecd) gene lead to third stage mutant larvae with reduced synthesis or release of the ecdysone hormone in the salivary glands when exposed to temperature stress (HeNRICH et al., 1987). A reduction in ecdysone affects the expression of a proneural gene called atonal (ato), which is responsible for initiating the process of the development of numberless segmentspecific sensorial organs including the eye, the hearing organ (Johnston's organ located in the antennae) and tension receptors (cordotonal organ located in the paws) (NIwA et al., 2004). The results obtained from the isostrain 31 , where the phenotypes with united antennae occurred only at $29^{\circ} \mathrm{C}$, may be related to this hypothesis, because when the control crossings were carried out without temperature stress in order to obtain stable strains, altered descendents were not produced.

The final hypothesis, which may explain the appearance of morphological alterations in $D$. willistoni 17A2 strain under temperature stress, may also be connected to proteins involved in the development processes and to the negative effects that higher temperatures may have on them. The higher temperature may interfere in the regulation pathways of embryonic development genes, in a way that mutations might not necessarily occur. Temperature shock during development induces morphological defects in vertebrates and invertebrates (Petersen \& Young, 1991).

The Heat Shock Proteins 90 (Hsp90) chaperones the maturation of many regulatory proteins and, in $D$. melanogaster, buffers genetic variation in morphogenetic pathways (QuerTsch et al., 2002). When Hsp90 buffering activity is compromised, by temperature for example, cryptic variants are expressed and selection can lead to the continued expression of these traits, even when Hsp90 function is restored (RUTHERFORD \& LINDQUIST, 1998). The loss of isostrains in this work may also be alternatively explained by impaired expression of HSPs. In $D$. melanogaster, alteration in Hsp70 induction is implicated in reduced fecundity (KreBs \& LoeschcKe, 1994), and overexpression of Hsp70 is associated with increased larval mortality (KREBS \& FEDER, 1997), retarded growth (FEDER et al., 1992), and reduced egg hatching (Silbermann \& TATAR, 2000).

Although the principal objective of the present study is the description of the phenotypes resulting from temperature stress in the 17A2 strain, it is possible to conclude that an intrinsic source of genetic variability exists in this strain, although it still remains to be found. None of the three hypothesis discussed above excludes the others and they may indeed be operating simultaneously. More focused experiments are still necessary in the future to identify with greater accuracy which agents are causing the alterations. However, it can be said that this present work has characterized the $D$. willistoni 17A2 strain as a hypermutable strain.

Acknowledgments. The authors would particularly like to thank Ardala Breda, Hermes J. Schmitz and Lizandra J. Robe and for English revision and Luis Fernando M. Fonte for helpful suggestions on the pictures. This study was supported by the Brazilian Agencies CNPq and PROPESQ-UFRGS (fellowships and grants).

\section{REFERENCES}

Alonso-Gonzalez, L.; Domínguez, A. \& Albornoz , J. 2006. Direct determination of the influence of extreme temperature on transposition and structural mutation rates of Drosophila melanogaster mobile elements. Genetica 128:11-19.

Arnault, C.; Loevenbruck, C. \& Biemont, C. 1997. Transposable element mobilization is not induced by heat shocks in Drosophila melanogaster. Naturwissenschaften 84:410-414.

Ayala, F. J. \& Powell, J. R. 1972. Enzyme variability in the Drosophila willistoni group. Biochemical Genetics 7(3):331-345.

Brower, D. L. \& JAFFe, S. M. 1989. Requirement for integrins during Drosophila wing development. Nature 342:285-287.

Bryant, P. J. 1978. Pattern formation in imaginal discs. In: Ashburner, M. \& Wright, T. R. F. eds. The Genetics and Biology of Drosophila, Academic Press. v.2c, p.229-335.

Capy, P.; Bazin, C.; Higuet, D. \& Lagin, T. 1998. Dynamics and evolution of transposable elements. Austin, TexasLandes Biosciences. 197p.

Chen, B.; Walser, J. C.; Rodgers, T. H.; Sobota, R. S. ; Burke, M. K.; Rose, M. R. \& Feder M. E. 2007. Abundant, diverse, and consequential $P$ elements segregate in promoters of small heat-shock genes in Drosophila populations. Journal of Evolutionary Biology 20(5):2056-2066.

Dressen, T. D.; Johnson, D. H. \& Henikoff, F. S. 1988. The brown protein of Drosophila melanogaster is similar to the white protein and components of active transport complexes. Molecular Cell Biology 8:5206-5215.

Engels, W. 1989. P Elements in Drosophila melanogaster. In: Berg, D. E. \& Howe, M. M. eds. Mobile DNA. American Society for Microbiology. p.437-484.

Engels, W. R. \& Preston, C. R. 1980. Components of hybrid dysgenesis in a wild population of Drosophila melanogaster. Genetics 95:111-128.

Ephrussi, B. \& Beadle, G. W. 1936. A technique of transplantation for Drosophila melanogaster. American Naturalist 70:218-225.

Feder, M. E \& Hoffmann, G. E. 1999. Heat-shock proteins, molecular chaperones, and the stress response: evolutionary and ecological physiology. Annual Review of Physiology 61:243-282. 
Feder, M. E. 1996. Ecological and evolutionary physiology of stress proteins and the stress response: the Drosophila melanogaster model. In: Johnston, I. A. \& Bennet, A. F. eds. Animals and temperature. Cambridge University Press. p.79-102.

Feder, M. E.; Cartaño, N. V.; Milos, L.; Krebs, R. A. \& Lindquist, S. L. 1996. Effect of engineering hsp70 copy number on Hsp70 expression and tolerance of ecologically relevant heatshock in larvae and pupae of Drosophila melanogaster. Journal of Experimental Biology 199:1837-1844.

Feder, M. E.; Rossi, J. M.; Solomon, J.; Solomon, N. \& Lindquist, S. 1992. The consequences of expressing HSP70 in Drosophila cells at normal temperatures. Genes \& Development 6:1402-1413

Finnegan, D. J. 1990. Transposable elements. Drosophila Information Service 68:371-381.

Fishilevich, E. \& Vosshall, L. B. 2005. Genetic and functional subdivision of the Drosophila antennal lobe. Current Biology 15(17):1548-1553.

Fristrom D.; Wilcox, M. \& Fristrom, J. W. 1993. The distribution of PS integrins, Laminin A and F-actin during key stages in Drosophila wing development. Development 117:509-523.

Futuyma, D. J. 1992. Biologia Evolutiva. Sociedade Brasileira de Genética/CNPq, Ribeirão Preto. 631p.

Gardner, E. J. \& Snustad, D. P. 1986. Genética. Guanabara Koogan, Rio de Janeiro. 756p.

GeHring, W. J. 2001. The genetic control of eye development and its implications for the evolution of the various eye types. Zoology 104:171-183.

Gibert, J. M.; Peronnet, F. \& Schlötterer, C. 2007. Phenotypic plasticity in Drosophila pigmentation caused by temperature sensitivity of a chromatin regulator network. PLoS Genetics 3(2):266-280.

Gong, W. J. \& Golic, K. G. 2006. Loss of HSP70 in Drosophila is pleiotropic, with effects on thermotolerance, recovery from heat-shock and neurodegeneration. Genetics 172:275-286.

Goñi, B.; Rohde, C. \& Valente, V. L. S. 2002. Genetic characterization of spontaneous mutations in Drosophila willistoni. I. Exchange and non-disjunction of the $\mathrm{X}$ chromosome. Drosophila Information Service 85:80-84.

Göpfert, M. C. \& RoBert, D. 2001. Turning the key on Drosophila audition. Nature 411:908.

Griffiths, A. J.; Miller, J. H.; Suzuki, D. T.; Lewontin, R. C. \& Gelbart, W. M. 1996. An Introduction to Genetic Analysis. W. H. Freeman and Company, New York, 916p.

Harada, K.; Yukushiro, K. \& MuKaI, T. 1990. Transposition rates of mobile genetic elements in Drosophila melanogaster. Proceedings of the National Academy of Sciences of USA 87:3248-3252.

Henrich, V. C.; Tucker, R. L.; Maroni, G. \& Gilbert, L. I. 1987. The ecdysoneless (ecd $1^{\text {ts }}$ ) mutation disrupts ecdysteroid synthesis autonomously in the ring gland of Drosophila melanogaster. Developmental Biology 120:50-55.

Hoffmann A. A. \& Hercus M. J. 2000. Environmental stress as an evolutionary force. Bioscience 50:217-226.

Hoffmann A. A. \& Parsons P. A. 1991. Evolutionary genetics and environmental stress. Oxford University Press, New York. 284p.

Hoffmann, A. A ; Dagher, H.; Hercus, M. \& Berrigan, D. 1997. Comparing different measures of heat resistance in selected lines of Drosophila melanogaster. Journal of Insect Physiology 43:393-405.

Kalendar, R.; Tanskanen, J.; Immonen, S.; Nevo, E. \& Schulman, A. H. 2000. Genome evolution of wild barley (Hordeum spontaneum) by BARE-1 retrotransposon dynamics in response to sharp microclimatic divergence. Proceedings of the National Academy of Sciences of USA 97:6603-6607.

Krebs, R. A. \& Feder, M. E. 1997. Deleterious consequences of HSP70 overexpression in Drosophila melanogaster larvae. Cell Stress Chaperones 2:60-71.

Krebs, R. A. \& LoeschCKe, V. 1994. Costs and benefits of activation of the heat-shock response in Drosophila melanogaster. Functional Ecology 8:730-737.

Kristensen, T. N.; Sørensen, P.; Kruhøffer, M.; Pedersen, K. S. \& LOESCHCKe, V. 2005. Genome wide analysis of inbreeding effects on gene expression in Drosophila melanogaster. Genetics 171:157-167.

Kristensen, T. N.; Sørensen, P.; Pedersen, K. S.; Kruhøffer, M. \& LoEschCKe, V. 2006. Inbreeding by environmental interactions affect gene expression in Drosophila melanogaster. Genetics 173:1329-1336.

Landis, G. N.; Abdueva, D.; Skvortsov, D.; Yang, J.; Rabin, B. E.; Carrick, J.; Tavare, S. \& Tower, J. 2004. Similar gene expression patterns characterize aging and oxidative stress in Drosophila melanogaster. Proceedings of The National Academy of Sciences of USA 101:7663-7668.

Lindquist, S. \& Craig, E. A. 1988. The heat-shock proteins. Annual Review of Genetics 22:631-677.

LINDQUIST, S. 1981. Regulation of protein synthesis during heatshock. Nature 293:311-314.

Lindsley, D. L. \& Zimm, G. G. 1992. The genome of Drosophila melanogaster. Academic Press, San Diego. 1133p.

Loeschcke, V.; Krebs, R. A.; Dahlgraard, J. \& Michalak, P. 1997. High-temperature stress and the evolution of termal resistance in Drosophila. In: Bislsma, R. \& Loeschcкe, V. eds. Enviromental Stress, Adaptation and Evolution. Birkhäuser Verlag Basel/Switzerland. p.175-190.

LoReto, E. L. S.; ZAHA, A. \& VALEnTE, V. L. S. 1998. Characterization of a hypermutable strain of Drosophila simulans. Cell Molecular Life Science 54:1283-1290.

Ludwig, A.; Parada, C.; Loreto, E. L. S. \& GoÑI, B. 2003. Genetics and molecular analysis of a Drosophila willistoni spontaneous mutation similar to eyeless. Drosophila Information Service 86:138-142.

Marques, E. K.; Napp, M.; Winge, H. \& Cordeiro, A. R. 1966. A corn meal, soybean flour, wheat germ medium for Drosophila. Drosophila Information Service 41:187.

Milton, C. C.; Batterham P.; McKenzie, J. A. \& Hoffmann, A. A. 2005. Effect of $E(\mathrm{sev})$ and $S u(R a f)$ Hsp83 mutants and transheterozygotes on bristle trait means and variation in Drosophila melanogaster. Genetics 171:119-130.

Morimoto, R. I.; Jurivich, D. A.; Kroeger, R. E.; Mathur, S. K.; Murphy, S. P.; Nakai, A.; Sarge, K., Abravaya, K. \& Sistonen, L. T. 1994. Regulation of heat shock gene expression by a family of heat shock factors. In: MоRiмото, R. I.; Tissieres, A. \& Georgopoulos, C. eds. The biology of heat shock proteins and molecular chaperones. Cold Spring Harbor Laboratory Press, NY. p.417-455.

Nielsen, M. M.; Sørensen, J. G.; Kruhøffer, M.; Justesen, J. \& Loeschcke, V. 2006. Phototransduction genes are upregulated in a global gene expression study of Drosophila melanogaster selected for heat resistance. Cell Stress Chaperones 11:325-333.

Niwa, N.; Horomi, Y. \& Окаве, M. 2004. A conserved developmental program for sensory organ formation in Drosophila melanogaster. Nature Genetics 36(3):293-297.

Nuzhdin, S. V. \& MaCKAY, T. F. C. 1995. The genomic rate of transposable element movement in Drosophila melanogaster. Molecular Biology and Evolution 21:180-181.

Parsell, D. A.; Taulien J. \& Lindquist S. 1993. The role of heatshock proteins in thermotolerance. Philosophical Transactions of the Royal Society of London Series BBiological Sciences 339:279-285.

Pedersen, K. S.; Kristensen, T. N. \& Loeschcke, V. 2005. Effects of inbreeding and rate of inbreeding in Drosophila melanogaster - Hsp70 expression and fitness. Journal of Evolutionary Biology 18:756-762.

Petersen, N. S \& Young, P. 1991. Effects of heat shock on development and Actin mRNA stability in Drosophila. In MaresCA, D. \& Lindquist, S. eds. Heat Shock. Berlin Heidelberg, Springer-Verlag. p.155-161.

Pletcher, S. D.; Macdonald, S. J.; Marguerie, R.; Certa, U.; Stearns, S. C.; Goldstein, D. B. \& Partridge, L. 2002. Genome-wide transcript profiles in aging and calorically restricted Drosophila melanogaster. Current Biology 12:712-723.

Queitsch, C.; Sangster, T. A. \& Lindquist, S. 2002. Hsp90 as a capacitor of phenotypic variation. Nature 417:598-599.

Ratner, V. A.; Zabanov, S. A.; Kolesnikova, O. V. \& Vasilyeva, L. A. 1992. Induction of the mobile genetic element $D m-412$ transpositions in the Drosophila genome by heat shock treatment. Proceedings of the National Academy of Sciences of USA 89:5650-5654. 
Regner, L. P.; Abdelhay, E.; Rohde, C.; Rodrigues, J. J. S. \& VALENTE, V. L. S. 1999. Temperature-dependent gonadal hybrid dysgenesis in Drosophila willistoni. Genetics and Molecular Biology 22(2):205-211.

Regner, L. P.; Pereira, M. S. O.; Alonso, C. E. V.; Abdelhay, E. \& Valente, V. L. S. 1996. Genomic distribution of $P$ elements in Drosophila willistoni and search for their relationship with chromosomal inversions. Journal of Heredity 87(2):190-211.

Rutherford, S. L. \& LindQuist, S. 1998. Hsp90 as a capacitor for morphological evolution. Nature 396:336-342.

Santos-Colares, M. C.; Degrandi, T. H. \& Valente, V. L. S. 2004 Cytological detection of male recombination in Drosophila willistoni. Cytologia 69(4):359-365.

Sassi, A. K; Herédia, F.; Loreto, E. L. S.; Valente, V. L. S.; Rohde, C. 2005. Transposable elements $P$ and gypsy in natural populations of Drosophila willistoni. Genetics and Molecular Biology 69(4):734-739.

Shine, R.; Harlow, P. S; Elphick, M. J.; Olsson, M. M. \& Mason, R. T. 2000. Conflicts between courtship and thermoregulation: the thermal ecology of amorous male garter snakes (Thamnophilis sirtalis parietalis, Colubridae). Physiological and Biochemical Zoology 73:508-513.

Silbermann, R. \& TATAR, M. 2000. Reproductive costs of heatshock protein in transgenic Drosophila melanogaster. Evolution 54:2038-2045.

Sørensen, J. G.; Kristensen, T. N. \& Loeschcke, V. 2003. The evolutionary and ecological role of heat-shock proteins. Ecology Letters 6:1025-1037.

Sørensen, J. G.; Dahlgaard, J. \& Loeschcke, V. 2001. Genetic variation in thermal tolerance among natural populations of Drosophila buzzatii: down regulation of Hsp70 expression and variation in heat stress resistance traits. Functional Ecology 15:289-296.

Sørensen, J. G.; Nielsen, M. M. \& Loeschcke, V. 2007. Gene expression profile analysis of Drosophila melanogaster selected for resistance to environmental stressors. Journal of Evolutionary Biology 20(13):1624-1636.

Strand, D. J. \& McDonald, J. F. 1985. Copia is transcriptionally responsive to environmental stress. Nucleic Acids Research 13(12):4401-4410.

Sullivan, D. T. \& Sullivan, M. C. 1975. Transport defects as the physiological basis for eye color mutants of Drosophila melanogaster. Biochemical Genetics 13:603-613.

Tearle, R. G.; Belote, J. M.; McKeown, M.; Baker, B. S. \&
Howells, A. J. 1989. Cloning and characterization of scarlet gene of Drosophila melanogaster. Genetics 122:595-606.

Todi, S. V.; Sharma, Y. \& Eberl, D. F. 2004. Anatomical and molecular design of the Drosophila antenna as a flagellar auditory organ. Microscopy Research and Technique 63:388-399.

Torres, F. P.; Fonte, L. F.; Valente, V. L. S. \& Loreto E. L. 2006. Mobilization of a Hobo-related sequence in the genome of Drosophila simulans. Genetica 126:101-110.

Valiati, V. H.; Silva, N. M. \& Valente, V. L. S. 1999. Spontaneous mutant phenotypes found in urban $D$. paulistorum and $D$. willistoni populations. Drosophila Information Service 82:123-125.

Vasilyeva, L. A.; Bubenshchikova, E. V. \& Ratner, V. A. 1999. Heavy heat shock induced retrotransposon transposition in Drosophila. Genetical Research Cambridge 74:111-119.

VÁsquez, J. F.; Albornoz, J. \& Dominguez, A. 2007.Direct determination of the effects of genotype and extreme temperature on the transposition of roo in long-term mutation accumulation lines of Drosophila melanogaster. Molecular Genetics and Genomics, 278:653-664.

VieirA, C. \& BiÉMONT, C. 1996. Geographical variation in insertion site number of retrotransposon 412 in Drosophila simulans. Journal of Molecular Evolution 42:443-451.

Vieira, C.; Aubry, P.; Lepetit, D.; BiÉmont, C. 1998. A temperature cline in copy number for 412 but not roo/B104 retrotransposons in populations of Drosophila simulans. Proceedings of the Royal Society of London Series BBiological Sciences 265:1161-1165.

Walser, J. C.; Chen B. \&, Feder M. E. 2006. Heat-shock promoters: targets for evolution by P transposable elements in Drosophila. PLoS Genetics 2(10):e165.

Welte, M. A.; Tetrault, J. M.; Dellavalle, R. P. \& Lindquist, S. L. 1993. A new method for manipulating transgenes: engineering heat tolerance in a complex, multicellular organism. Current Biology 3:842-853.

WilcoX, M.; DiAntonio, A. \& Leptin, M. 1989. The function of PS integrins in Drosophila wing morphogenesis. Development 107:891-897.

Zabanov, S. A.; Vasilyeva, L. A. \& Ratner, V. A. 1994. Multiple inductions of transpositions of mobile genetic element B104 in Drosophila with severe heat shock. Genetika 30:218-224.

Zusman, S.; Patel-King, R. S.; French-constant, C. \& Hynes, R. O. 1990. Requirements for integrins during Drosophila development. Development 108:391-402. 